\begin{tabular}{ll}
\hline 論 & 説 \\
\hline
\end{tabular}

\title{
両側小耳症・外耳道閉鎖に対する手術
}

-2 つ耳の形と機能を再建する一

加我 君孝1) ・ 朝戸 裕貴 ${ }^{2}$

\section{Cooperative Reconstructive Surgery for Children with Bilateral Microtia and Atresia for Esthetically and Functionally Better Results}

\author{
Kimitaka Kaga \\ (University of Tokyo) \\ Hirotaka Asato \\ (Dokkyo Medical University)
}

\begin{abstract}
In two stages of total ear reconstruction surgery for children with microtia and atresia, plastic surgeons and otologists have cooperated to reduce the number of surgeries and to achieve both esthetically and functionally better results. Ear elevation, external canal plasty and tympanoplasty are performed cooperatively in the second stage of surgery.

In the past 5 years we have experienced 70 cases of combined surgery as the second stage of microtia reconstruction: 59 boys and 11 girls, 12 cases of bilateral microtia and atresia and 58 cases of unilateral microtia and atresia. Analysis of the 3D CT scan was useful to plan total reconstruction surgery for microtia and atresia, and was important for education and design of surgery. Esthetically and functionally combined surgery at the second stage is convenient to make a natural orifice of the external canal, elevate the external ear and reconstruct the ossicular chain.

After bilateral reconstructive surgery, patients with bilateral microtia and atresia can localize sounds in the right and left auditory spaces.
\end{abstract}

Key words : microtia and atresia, combined surgery, 3D CT of ears, auditory space

はじめに

耳科学のゴールは何か.すべての耳疾患を治療し, 耳 介や外耳道に形状の異常があれば，両耳とも整容的に良 好に再建し，聴覚障害があれば聴覚を回復させ両耳聴を 再び享受できるようにすることではないか. 10 年以上前
にある国際学会で同席したスコットランドの先生との議 論の結論である，それ以来，両耳聴の実現を考えるよう になった1).

耳介の形状の先天異常, すなわち片側の小耳症は出生 数 1 万に 1 人, すなわち毎年約 120 名出生し, 両側の小

1) 東京大学耳鼻咽喉科学教室

2）独協医科大学病院形成外科 
耳症は 10 万に 1 人，すなわち毎年約 12 名が出生すると 見込まれる。われわ机は身体に目に見える異常があると 身体的なコンプレックスを持ちやすい2．見かけ上の異 常はそれだけ本人が気にすることにつながる。 大きな異 常より小さな異常の方がより気にするといら22. 小耳症 の場合，手術で良い形状の耳介を得た患者は喜び，自信 を持つ ${ }^{3)}$.この自信というのはこれまで引け目に感じて いた心理加ら解放され自由になったといら意味である う.

難聴は目に見えない。片側の難聴をきたす疾患も聴力 を取り戻し両耳聴を利用できるようにしたいが，反対側 が正常であるからとわれわれも妥協したりする。両側難 聴の場合はとりあえず片方を治すことに専念する. 反対 側についてはそれからであるが，最高の目標は両耳聴が 可能になるように治療することをゴールとしたい。

本稿では内容をわかりやすくするために片側小耳症外 耳道閉鎖の場合も含めて解説する。

\section{DCT という設計図による診断と術式の計画}

小耳症は片側性と両側性がある。片側性の場合，健側 が正常聴力のことが多く,耳介形成を形成外科で行うが， 外耳道形成は患者が希望する場合としない場合がある。 われわれの病院では, Jahrsdoerfer の側頭骨 CT の評価尺 度で良好であれば形成外科と耳鼻咽喉科の同日合同手術 を行っている4)51

1）初回手術を東大方式で行う場合

3DCT により側頭部の軟部組織と頭蓋骨の側頭部をと

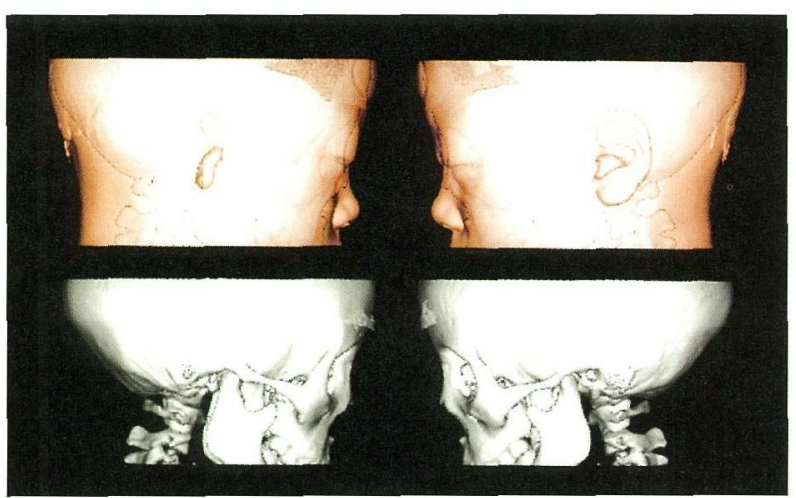

図 1 小耳症・外耳道形成術のための 3DCT. 右小耳症 III 度, 左は正常耳.上段は耳介を中心に皮膚と頭蓋を重称合わ せた画像。下段は頭蓋骨のみの画像. 右は鼓室骨が欠損 し，残存耳介である耳垂は乳突部より前方にあることが わかる。
れぞれ再構筑して，耳介と外耳道を再建する位置の基䃈 資料とする。耳介・外耳道形成のための設計図となる。 外耳道は mastoid 作ることになるため，耳介の位置は， 健側より約 $1 \mathrm{~cm}$ 後方になる。この $3 \mathrm{DCT}$ の画像注患者 およびその両親にとっても理解しやすい（図 1)。

小耳症・外耳道閉鎖症に対する術式は2段階手術を行っ ている. 手術の回数を減らすだけでなく整容的にも機能 的にも理想的な到達度を目指すためである。

(1)第一段階 形成外科単独の肋軟骨移植手術4)

VI，VII の肋軟骨（ガラス軟骨）を採取し，耳介の形状 にすべく耳介フレームワークをワイヤで組み合わせて作 成する。そのサイズは片側小耳症では，健側の耳介を参 考にする。両側小耳症では同年齢の子ぞもの耳介並びに 男なら父親，女なら母親の耳介のサイズを参考にする。 このようにサイズを決めた胁軟骨の耳介フレームワーク を側頭部の皮下に移植する（図 2)。その位置の決定には 2 回目の手術で作る外耳道入口部が乳突部にくるように 3DCT 参考汇行う。

(2)第二段階 形成外科と耳鼻咽喉科，合同同日手術5) 耳介挙上術と外耳道形成術，聴力改善手術

（1）形成外科医により移植してある肋軟骨の耳介フ レームワークの後方を持ち上げると同時に，その耳介の 外耳道入口部に相当する位置に直径約 $1.5 \mathrm{~cm}$ の外耳道孔 を作成する。側頭部皮下より temporo parietal flap および deep-innominate temporal fascia flap を作成する.形成する 外耳道のための皮膚管を作るべく鼠径部の全層皮膚ある いはPadgett で頭皮より分層皮膚を採皮する。前者は後 に外耳道に毛髪が出やすく感染の原因になりやすいが， 後者は气の心配が少ない。長さ $5 \mathrm{~cm}$ 直径 $2 \mathrm{~cm}$ 弱の皮膚 管を作る，先は盲端にすべく縫合する（図 3).

（2）耳鼻咽喉科医に術者が交代する。マーカーで mastoid tip, temporo parietal line および想定される外耳道 入口部に印をつける。外耳道入口部の後端に相当する個 所を切開し，筋膜，骨膜を pedicled flap にする。 mastoid の骨面より骨板を採取する。バーで antrotomy を行う。 anturmが同定されると,さらにmastoidectomyを行い桩大 する（図 4)。次に aditus ad antrum に向办って進み incus の短脚を同定すべく注意深く拡大する。短脚を発見した 後に，次に乳突部表面加占耳腔にいたる厚い閉鎖板を 削除し，耳小骨連鎖全体を露出させる。ほとんざが malleus incusが一つのcomplexとなった固まりとstapesが ある。多くの場合，handle が欠損している。周囲の骨や 


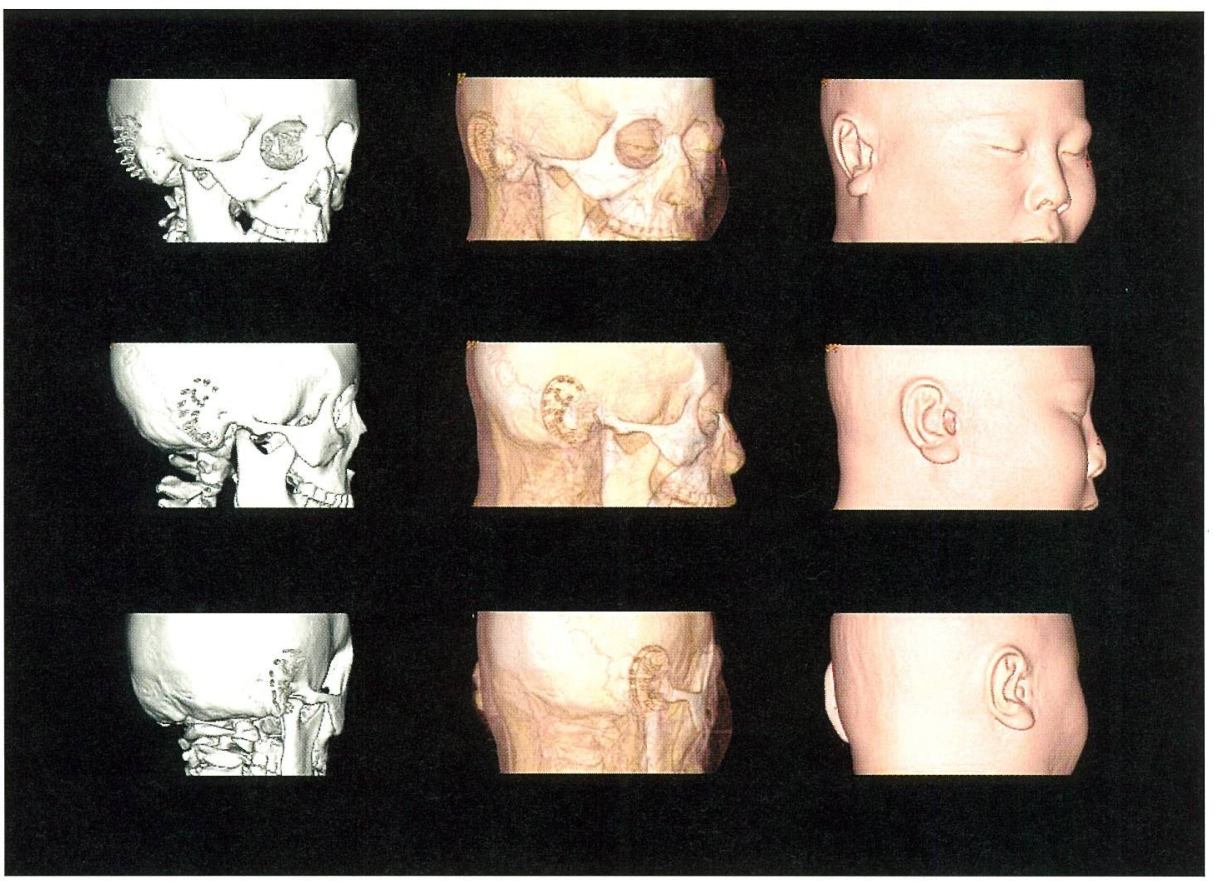

図 2 右小耳症に対する耳介形成術，合同手術の第一段階，形成外科による肋軟骨移植手術後の 3DCT (3 方向)。右は軟部組織の再 現.耳介の肋軟骨によるフレームが皮下に移植されただけであるが整容的に良好な耳介である。左は頭蓋骨とワイヤで結ばれた 肋軟骨の耳介フレームワークがわかる。真中はその両方を重初合わせた画像。これが第二段階手術となる耳介挙上術と外耳道形 成術の設計図となる。
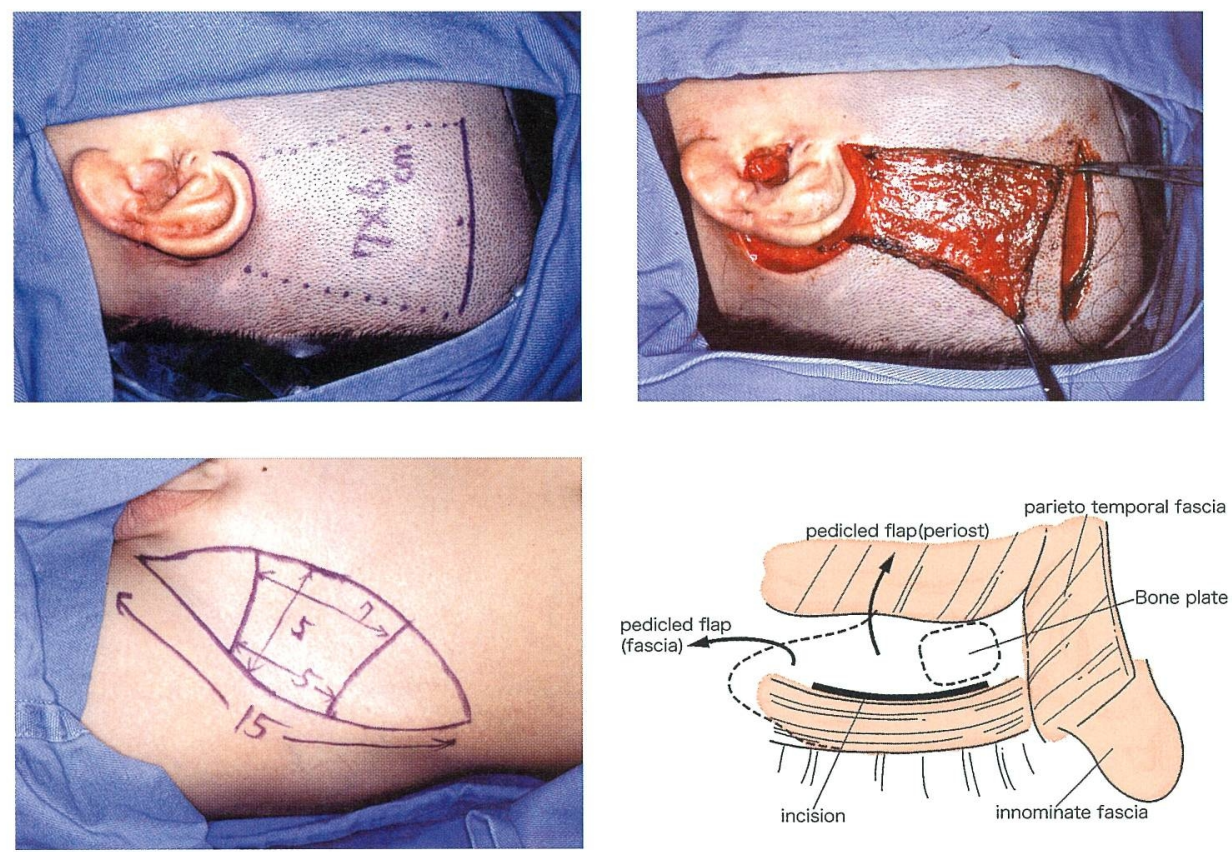

図 3 第二段階手術. 耳介挙上術と外耳道形成術

形成外科医により頭皮の皮下より temporo parietal flap（上段の左右）を作成する。外耳道形成のために鼠径部より皮膚管を準備 すべく，木の葉状の全層植皮を採皮する（下段左）。耳介後部を切開し起こす。ここで術者は耳科医に交代する。乳突部表層よ り骨板を採取し，ここは新たに作成する外耳道の中心部となる。 


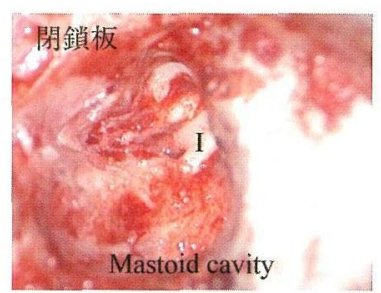

1

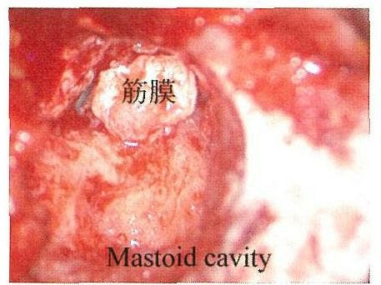

4

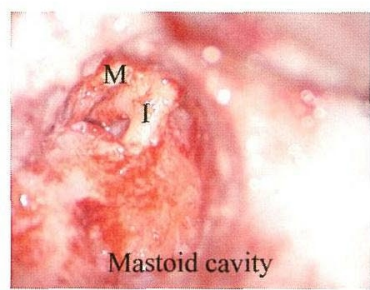

2

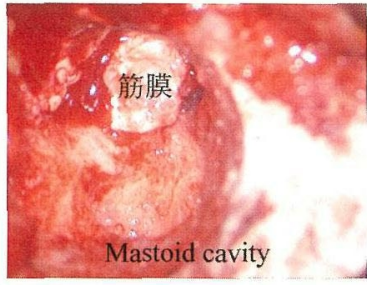

5

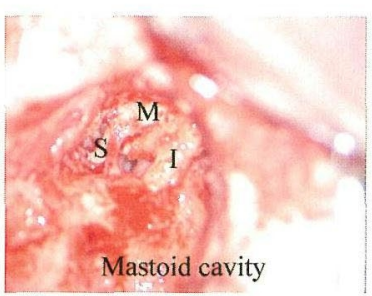

3

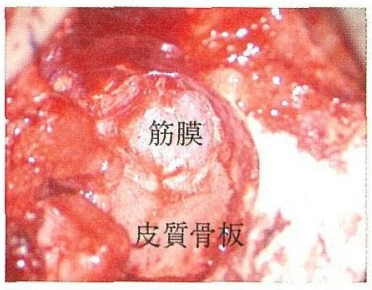

6

図 4 第二段階手術（1）

耳科医による外耳道形成術と聴力改善術。1. 乳突削開術。incus をさがす。2.Aditus 側に進み incus の短脚を同定する. 3. 閉 鎖板を削除しつち骨， stapes を確認する４４．電気刺激で耳小骨の可動性をチェックし確認した後，用意してあった骨板で外耳 道後壁を作成する． 5. 肋軟骨で作ったコルメラを malleus incus の complex の上に立てる. 筋膜で鼓膜を形成する. 6. 有茎の deep-innominate temporal fascia flap で新しい骨部外耳道の全体をカバーする。 M : malleus I：incus S : stapes
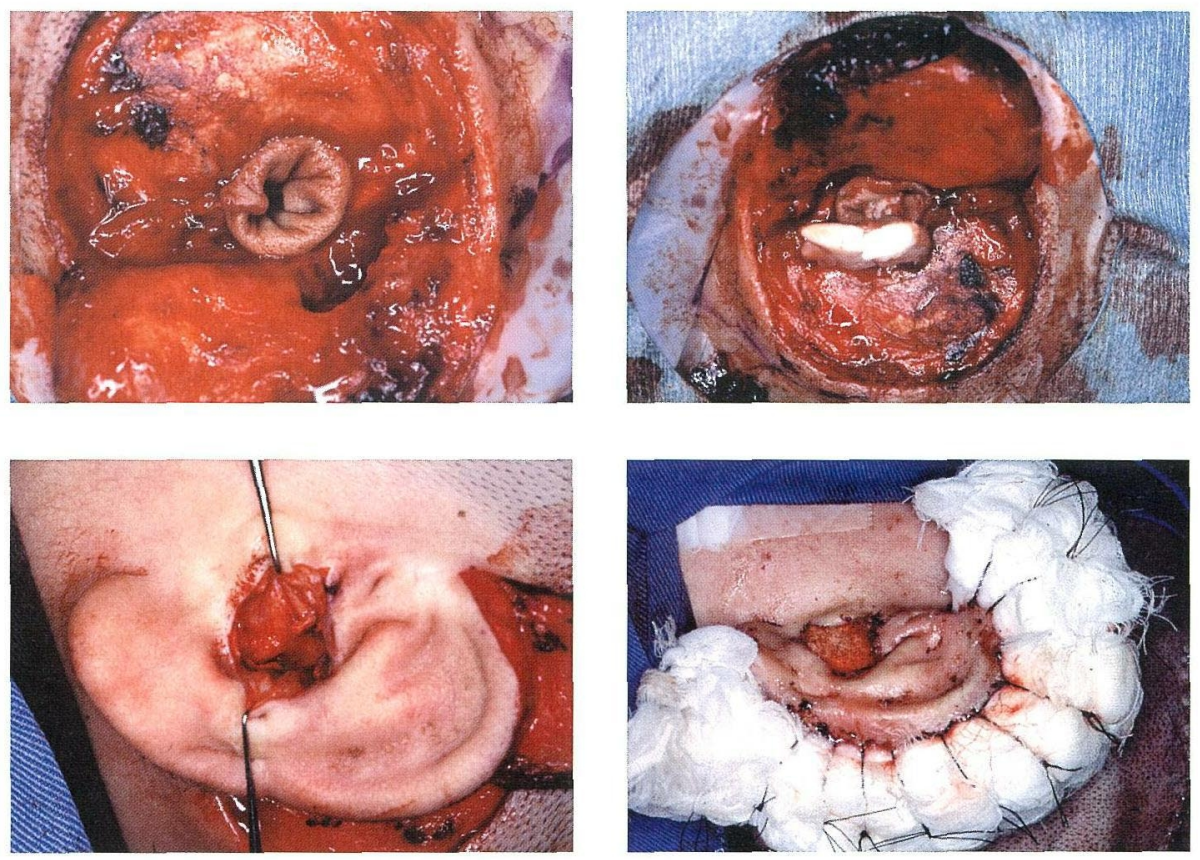

図 5 第二段階手術 (2)

用意してあった皮膚管を新しい外耳道に挿入し (左上), 再び形成外科医にバトンタッチする.すでに用意してあった banking 軟 骨のブロックを移植し，耳介を立てる素材とする．この上を有茎の temporo parietal fascia flap でカバーする，そして，耳後部全 体に植皮を行う（上段右）。皮膚管と外耳道入口部を縫合する（下段左）．形成した耳介はタイオーバーして圧迫する（下段右）。 
膜を除去し可動性が良好であることを確認する．顔面神 経に損傷が生じないように顔面神経電気刺激で顔面神経 の走行を確認しながら行う。 stapes の同定をしょうとす ると顔面神経の近くを削らなければならず危険である。 耳科手術用の内視鏡を使うと stapes を確認ができる。機 能的には顔面神経電気刺激で耳小骨が動くので同定がで きる。次に，すでに採取してあった骨板を用いて mastoidectomyによって生じた大きな cavityをカバーする ようにし, 外耳道後壁形成とする。肋軟骨の一部を用い てコルメラとして malleus-incus の complex の上に立て, フィブリン糊で固定する。その上に筋膜（innominate fascia の一部を採取）で鼓膜を形成する。この時にコルメ ラが筋膜より浮いて見えるようにすることが聴力改善の コッである。ささに deep-innominate temporal fascia flap をのばし，新をに形成された骨部外耳道全体がカバーさ
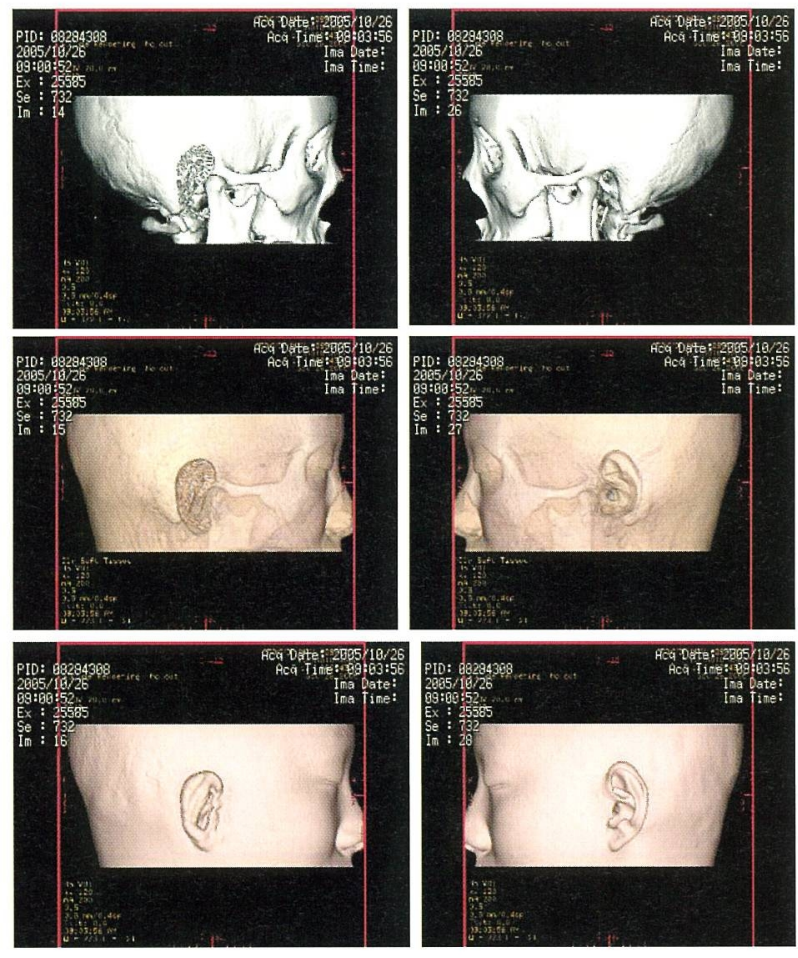

図 6 外耳道形成を予定せず，形成外科単独で行われた右耳介 形成術の 3DCT

右小耳症に対して外耳道形成の予定なく行われた耳介形 成.下段に軟部組織の画像を示す。見かけ上，右の形成 された耳介は整容的に良好.上段の頭蓋骨の3D 画像では 移植された肋軟骨のフレームは乳突部の前方，䫄関節の すぐ後方にあることがわかる，中段に，その両方を重ね 合わせた像を示す。もしこのままの状態で外耳道を作る とすると形成された耳介の後方にならざるをえない。
れるようにフィブリン糊で固定する，不足分は初めに作 成しておいた筋膜と骨膜の pedicled flap で補う。このよ うに準備して初めて皮膚管を挿入する。マーカーで色を つけたシルクガーゼを盲端の先端に入れ，その上に俵状 にした小コメガーゼを次々に挿入して固定する。フラッ プが動かないように注意深く行う（図 5)。

（3）再び耳科医より形成外科に交代する. banking 軟 骨のブロックを用いて耳介を立て固定する。耳後部全体 に予め用意してあった temporo parietal fasia flap で覆う。 その上を遊離植皮で覆い縫合する。外耳道入口部皮膚を 皮膚管と縫合する。耳介をタイオーバー固定する.

（4）抜糸と形成した外耳道内のシルクガーゼとコメ ガーゼの除去は 2 週間後に行う.

手術後, 左右の耳介の位置の差を気にすることはない. むしろ外耳道ができているので耳介は自然な形状に感じ られ, 手術したことが気がつかれないことも少なくない。

2)すべての耳介形成手術が形成外科単独で行われた場 合

形成外科が単独で片側の小耳症の手術を行う場合はほ とんど,形成されたその耳介は健側と同じ位置にある(図 6)。したがってその耳介を移動せずに外耳道を作ろうと

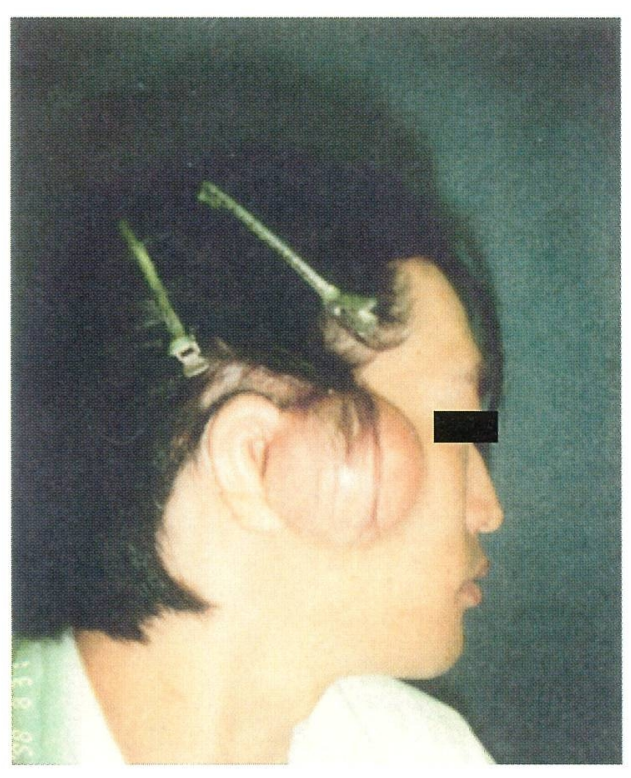

図 7 外耳道形成のための耳介後方移動法. 図 6 に示すように, 耳介を後方に移動するために皮膚を伸展する目的で皮下 にエキスパンダーを挿入. 数カ月挿入し皮膚が伸展した 後に耳介後方の移動と乳突部に外耳道を形成する準備を する。 
すると顎関節にあたるためそのままでは外耳道形成を行 うことは難しい，もしこの状態で外耳道形成を行うので あれば耳介を約 $1 \mathrm{~cm}$ 後方に移動させ, その後 mastoid に 外耳道形成手術を行うことになる。そのような場合に外 耳道形成を行らには頭部の皮下にexpanderを数力月挿入 し皮膚を伸展させてから, 耳介移動を乳突部まで行ら(図 7)。それが終了してから，外耳道形成莸行ら。この方式 は成人では受け入れられる分思春期の女子の患者は希望 しないことが多い。両耳とも形成外科単独で耳介形成の み行った子どもは耳介付着部は左右とも顎関節の上に位 置する。もし外耳道形成術を行らとしても見かけ上小さ な風船を膨らましたよらにみえる expanderの使用は好ま れない. 結果的に外耳道形成を受けることなく骨導補聴 器で一生過ごすことになる。成長とともに頭蓋骨が大き くなるためにヘッドバンドが厄介な存在となる。

\section{形成された耳介外耳道の特長}

\section{1）形状}

両側小耳症 ・外耳道閉鎖の術前の形状と術後の形状を 示す．外耳道が形成されていると整容的にも美しい例を 示す。聴力は術後変化が著しい, 両耳に耳穴式補聴器を 使用している(図 8 上段)。両側良好な聴力と美しい形成 耳介方形成され補聴器不用の例を示す (図 8 下段)。

2) 恥力

図 9 に片側・両側小耳症を含めた 48 例の術前と術後の 聴力レベルを示した。ほぼ全例とも術前より恥力レベル も良好であるが $30 \mathrm{~dB}$ 以内に入っているのは 12 例（25 \%) であり，2/3 は補聴を必要とする。図 8 上段に両側 小耳症の例の聴力の変化と耳穴式の補聴器を示した。両 側小耳症・外耳道閉鎖の場合, 両耳に耳穴式補聴器を使 用し，それまでのへアバンド式の骨導補聴器より解放さ れる。

3）聴力の改善が期待通りでない原因について
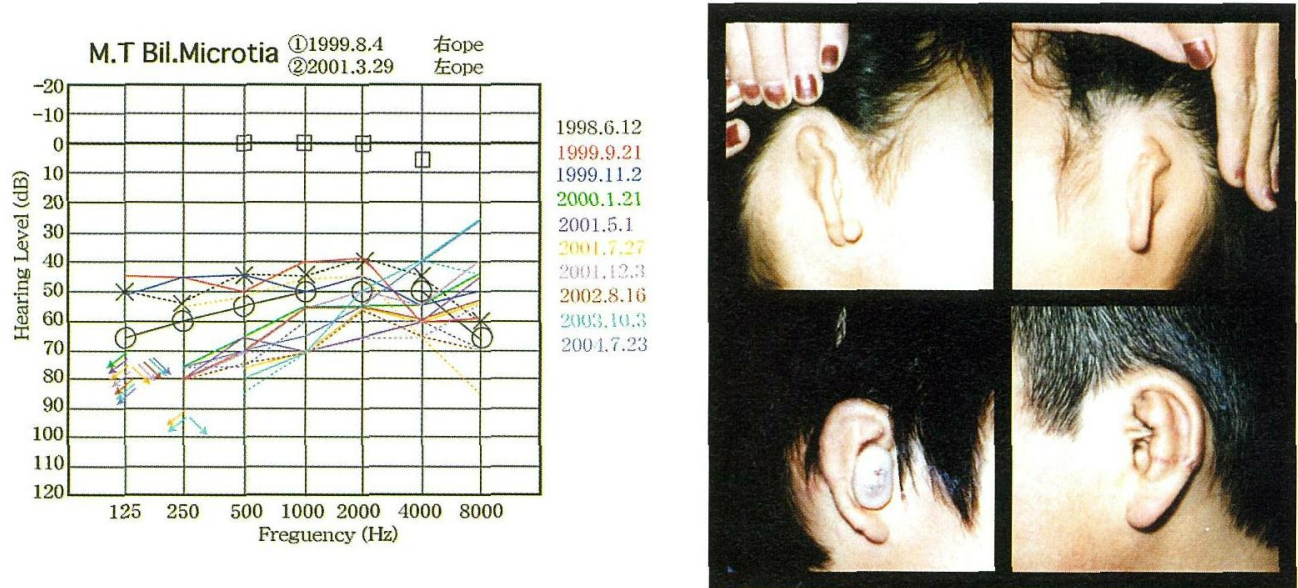

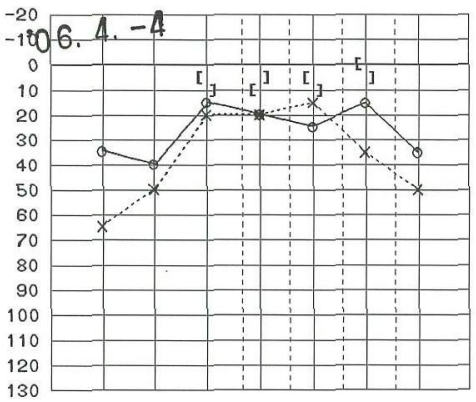

$125250500 \quad 1000200040008000$ FREQUENCY (Hz)
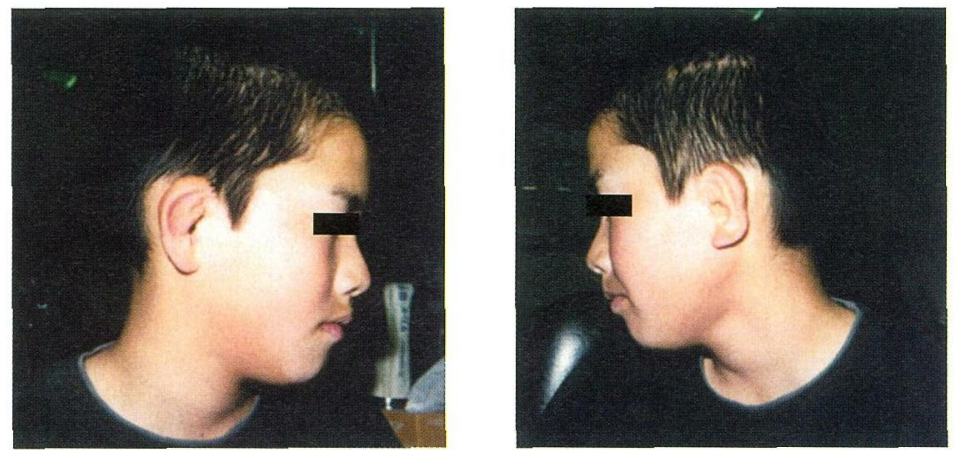

図 8 上段，両側小耳症・外耳道閉鎖術の術前術後の比較。恥力が実用的なレベルに改善しない場合は耳穴式補聴器を使用．耳介は整 容的に良好。下段，両側小耳症・外耳道閉鎖の術後の形態，機能乙も良好な例. 


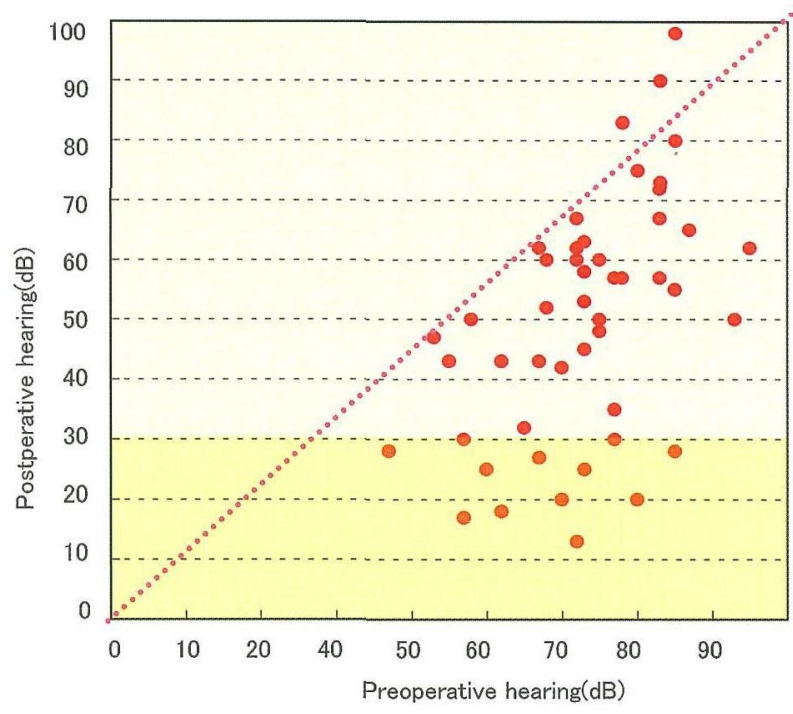

図 9 小耳症・外耳道閉鎖症例（片側・両側小例含を 48 例）の 術前・術後の聴力レベルの比較. 横軸が術前, 縦軸が術 後の聴力レベルを示す. 1/4 は聴カレベルは $30 \mathrm{~dB}$ 以上に 改善している。

術直後聴力が良いが，その後低下したり，初めから聴 力が改善しない場合がある。その主要な原因は(1)鼓膜の 浅在化。すなわち形成した鼓膜が外側へ移動し耳小骨汃 らはずれる（図 10）。(2)外耳道皮膚の肥厚と狭窄。感染 などによる線維化。(3)骨増殖による狭窄。外耳道骨部の 増殖。(4)鼓膜に骨膜を使用すると骨膜为骨化することが ある。いずれにしろ CT で診断し聴力改善のための再手 術を予定する6).

4）術後の一過性の顔面神経麻痺

小耳症・外耳道閉鎖に対する手術による恒久的な顔面 神経麻痺の頻度はSchulknecht ${ }^{7)}$ は 5/62(8\%), Jahrsdoerfer

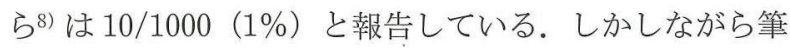
者らは 87 例 99 耳中 6 耳 $(6 \%)$ 飞一過性の顔面麻痺を経 験し全例とも後遺症なく回復した。恒久的な顔面神経麻 痺はない。一過性の麻疩の機序は(1)側頭骨がコンパクト な場合，バーによる drilling out によって熱が生じ，その 遠隔的伝導による一時的な熱による浮腫が生じる。(2)顔 面神経周囲の骨の drilling out による熱の近接効果などが 考えられる。顔面神経刺激装置を使って危険を回避する 限り, 直接に損傷を与え恒久的な麻痺の生じることは少 ないはずである9

5）術後の感染について

鼠径部の皮膚で外耳道形成手術を行った 68 例 80 耳中
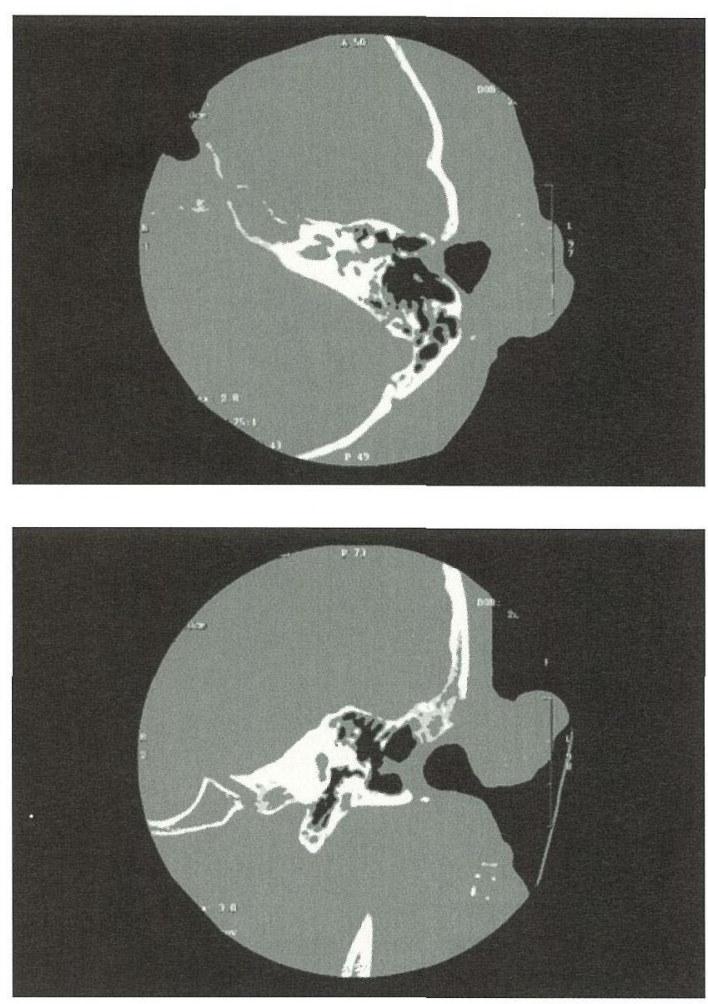

図 10 聴力が改善しない例の術後 CT（上段・水平段，下段・ 冠状断)。形成鼓膜の肥厚と leteralization によるコルメ ラと耳小骨の離断が生じている。

40 耳に一時的な感染があった。少数例であるが MRSA 感 染もあったが，しかし治療により全例とも治癒しケアフ リーになった。ただし，しばしば erosion が発生し，一 時的に耳漏が生じる例があり，感染のコントロールが必 要な例が $5 \%$ 未満存在する。これは鼠径部の皮膚より皮 膚管を作成した場合毛髪が生えることとの関係が疑われ る。というのは皮膚管の素材を鼠径部全層植皮片から頭 皮分層植皮片に変更してから 15 例の手術では外耳道の感 染がほとんどなくなったことである(図 11) 10)。このパー ジェットで採皮した頭皮には毛根がなく，外耳道皮膚に 毛が生えることはない ${ }^{11)}$ 。感染予防には骨部外耳道を deep-innominate fascia を活用するだけでなく皮膚管の素 材の選択も重要である.

\section{両耳 聴}

1) 骨導補恥器の周波数特性

両側小耳症・外耳道閉鎖症の患者の大部分は骨導聴力 は正常である。恐らく $8 \mathrm{kHz}$ を越える周波数でも sen- 


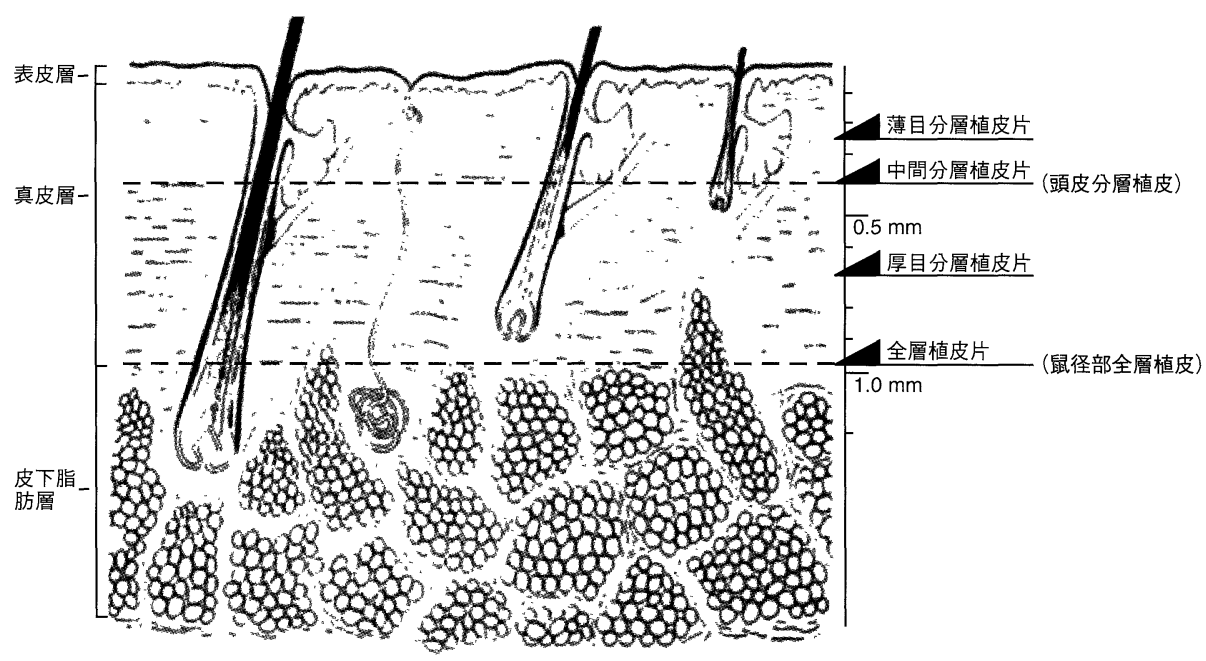

図 11 外耳道形成のための皮膚管の移植皮膚の比較. 鼠径皮部採取の全層植皮と頭皮分層植皮（split thickness）の模式図. (鬼塚卓弥：形成外科手術書，196910) より引用，一部改変）

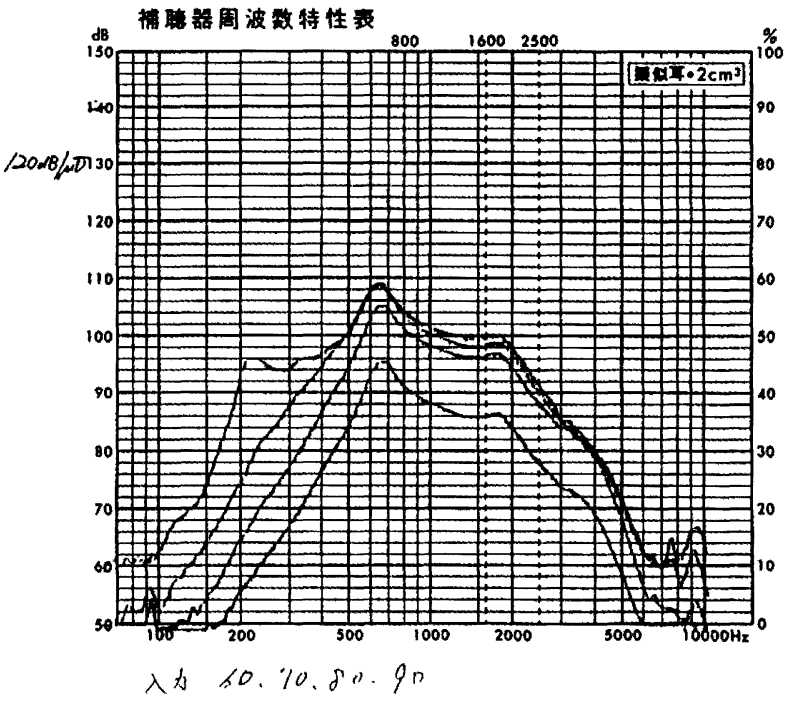

図 12 骨導補聴器の周波数特性. $600 \sim 700 \mathrm{~Hz}$ をピークとして $200 \sim 2000 \mathrm{~Hz}$ が増幅される. 両側小耳症 - 外耳道閉鎖 ではほとんどが骨導聴力は高い周波数でも正常であり， それを聴かせるような方法が無視されている。

sorineural な域值は健常例と同等と見込まれるが,それを 証明した報告はない。骨導補聴器の周波数特性曲線は図 12のごとく低・中音域值のみ増幅するようになっており， 気導補聴器と類似しているがカバーしている範囲は狭 い. 感音難聴では高音域が障害されていることが多く, そのため言葉を聴き取りやすくするために低中音域を増
幅するようになっている. 骨導補聴器の場合，その構造， すなわち電磁石方式のために限界があるため, 現在世界 中で Oticon 社製の骨導受話器が使用されている.これは 1985 年, ISO の委員会で決めたものである. しかし 20 年 以上過ぎ，技術が進歩している. 超磁歪素子を用いた革 新的な美しい音の骨導受話器が開発されている ${ }^{12}$.

1) 骨導受話器の固定位置

ほとんどの骨導受話器は耳後部の乳突部に fitting され ている．まれに前額部に置かれている場合がある（図 13). 骨導受話器は煩骨に置くのが最も能率が良いことが 切替等の研究で証明されており ${ }^{13)}$ ，主観的にもそうであ る．音の空気中の伝導速度は毎秒 $340 \mathrm{~m}$ であるが，一方 頭蓋骨の伝導速度は毎秒 $3000 \mathrm{~m}$ と速い，そのためにど こに置こうが両側の内耳がほとんど同時に刺激されてい るといらのが世界中のこれまでの考えの主流で，1 台の 骨導補聴器が使われてきた。 このようであっても, 聴覚 認知は正常なレベルに発達する. しかし, この方法で脳 の中で処理される方向感や音源定位能力は発達するであ ろらか。

2）両耳骨導が両耳聴を成立させることの証明

著者は両耳骨導補聴器は意味がないといら意見や，骨 導補聴器の単耳装用で十分であるとする習慣に疑問を持 ち，研究を進めてきた。

(1)方向感検査

両側の乳突部にそれぞれ骨導受話器を装着させ，リオ 


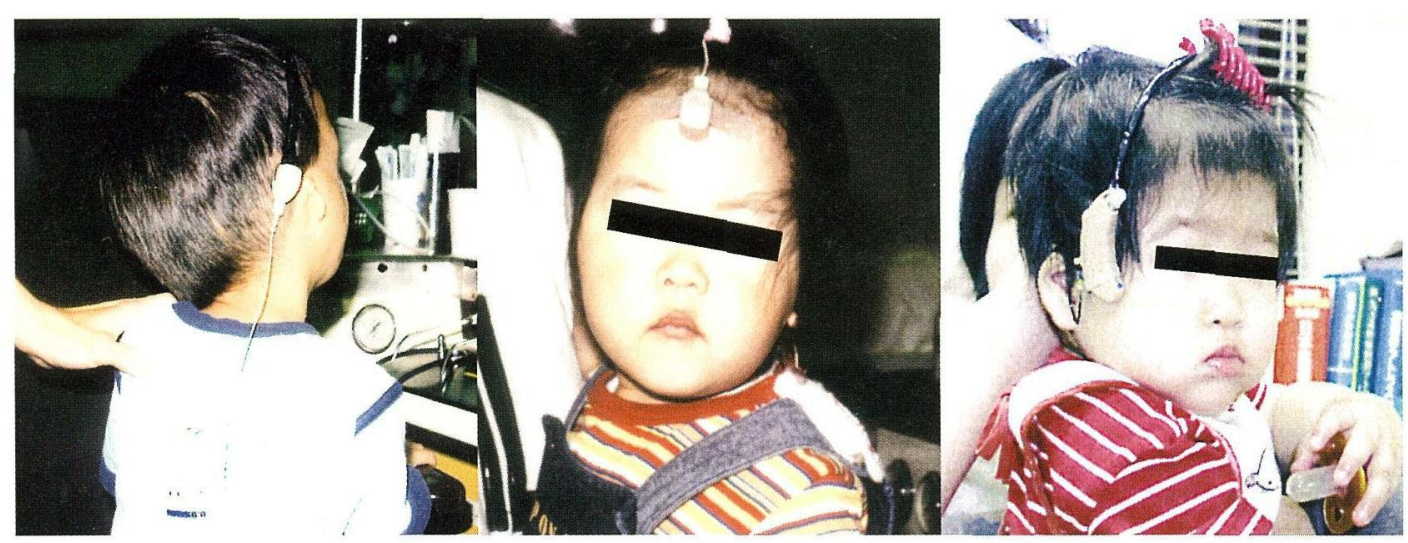

図 13 補聴器販売店が指導した両側小耳症外耳道閉鎖例に対する骨導補聴器の骨導受話器の位置とマイクロフォン・アンプ，バッテ リー本体の位置. 左 : 骨導受話器はへアバンドで耳後部, 本体は背中のシャツのポケット. 中 : 骨導受話器は前額部に両面テー プで貼りつけられ，ベビー型補聴器の本体は左肩にある，右：ヘアバンドで骨導受話器は左耳後部，耳掛型補恥器本体は右耳 前部.

Sound Lateralization Test

Patients

ITD

IID
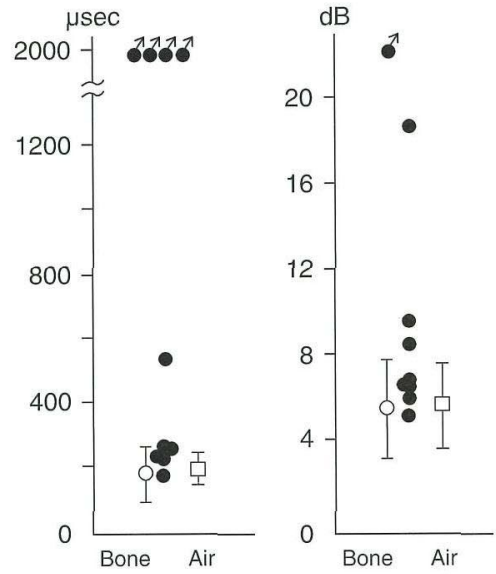

図 14 両側小耳症・外耳道閉鎖症の両側骨導による方向感検查 成績. Bone $(O)$ 骨導, Air : 対照例の耐側気導方向感 検查（口）。時間差（ITD）も音圧差（IID）も対照例と した気導方向感検查と差はない，ただしスケールアウト 例が存在するのが特徴である。

ン社の方向感検查装置と直接つなぎ，時間差と音圧差の 方向感の認知検查を行うと，健聴例でも両側小耳症・外 耳道閉鎖例のほとんどの症例でも成立することがわかっ た。時間差は気導での域值は約 $200 \mu \mathrm{sec}$ で，骨導でも同 様である。このことは両耳骨導補聴は意義があることを
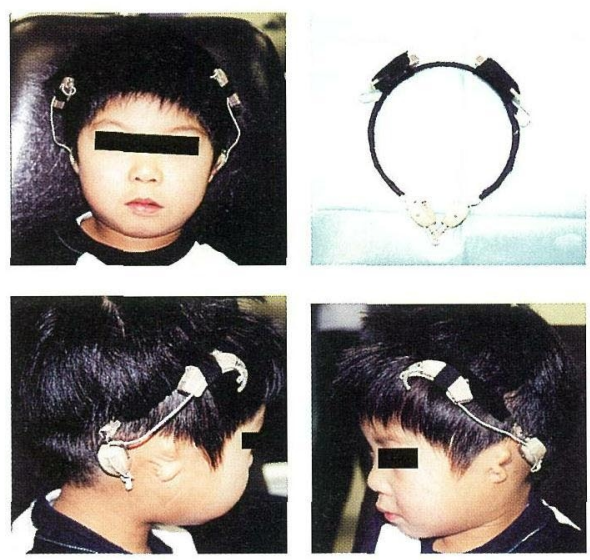

a

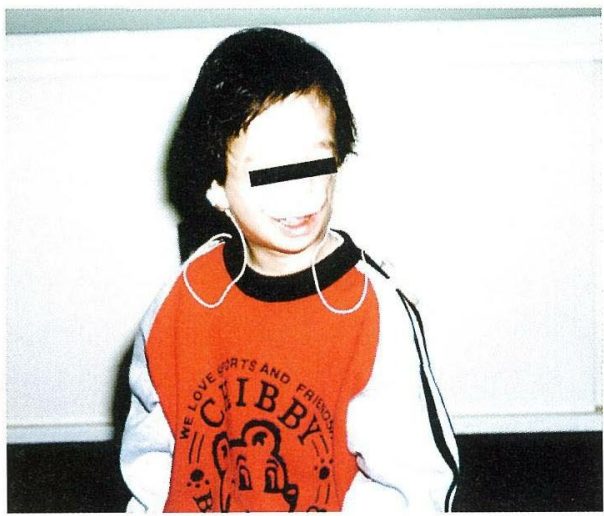

b

図 15 両側骨導補聴器装用例。a：母親の希望により秋田市の 補聴器販売店が作成したもので左右に骨導受話器と心゙ ビー型補聴器本体が配置されへアバンドでつながって いる.b：母親の考案によるもので両面テープで每日骨 導受話器を固定している. 


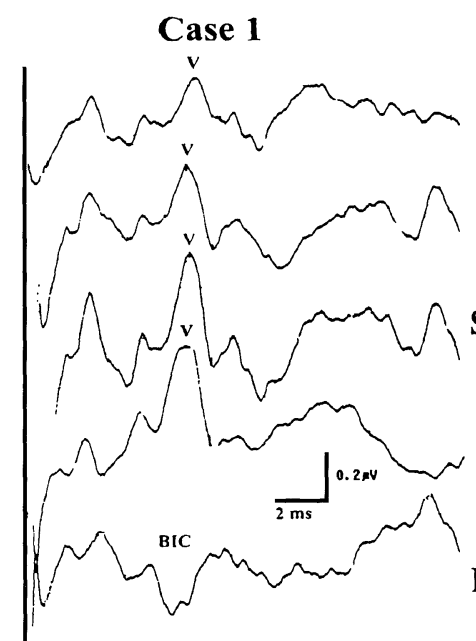

Case 3

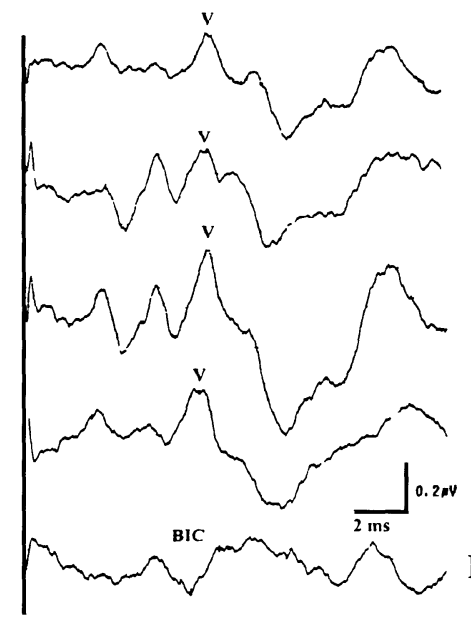

Rt.

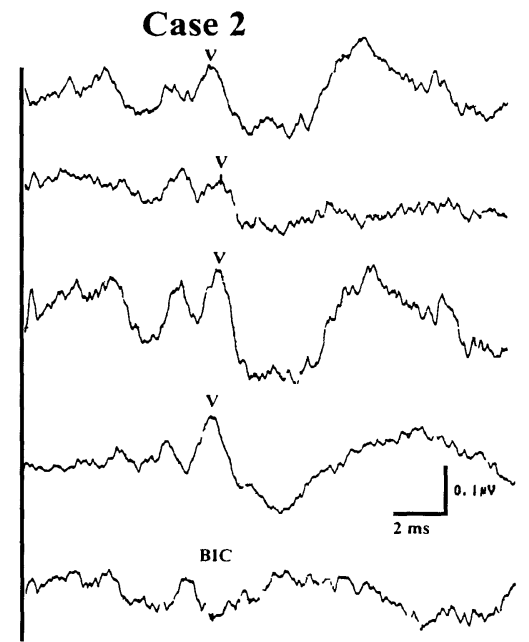

Case 4

Rt.

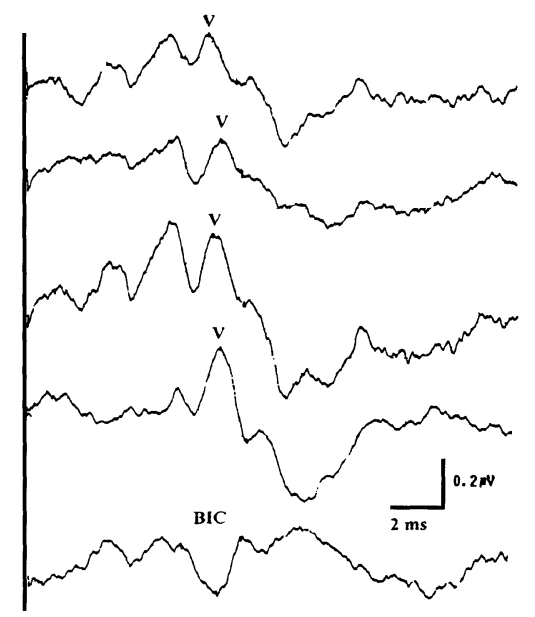

図 16 両側骨導 $\mathrm{ABR}$ による両耳干渉作用. 4 例の結果を示す. Rt：右刺激, Lt：左刺激. Sum：右，左の ABR の和，B：両側同時刺 激, BIC（両耳干渉電位）すなわち B - 1/2 × (Rt + Lt)。 4 例とも wave III, IV, V complex 領域に BIC を認める.

示す（図 14）。筆者はこの結果を 1996 年の米国の ARO でポスター展示をしたが，信じられないという反応で あった ${ }^{14)}$. 一方，両側小耳症・外耳道閉鎖を持つ子ども の母親が地方の補聴器販売店と相談して両耳骨導補聴器 を作ってもらっているような場合にしばしば出会うこと があり，現実の世界の方が先行していたのである（図 15).

(2)両耳骨導刺激による ABR の両耳融合現象

気導 $\mathrm{ABR}$ で両耳同時刺激で記録し, 単耳刺激とのサ ブトラクションを行うと，III, IV, V 波の振幅が大きくな る.これを両耳融合現象という。骨導 ABR で両耳同時 刺激を行うと, 同様に III 〜 V 波の振幅が大きくなり, 他 覚的に骨導の両耳融合現象が明らかになった ${ }^{15) 16)}$ (図
16).

(3)骨導方向感検查による Time-Intensity Trade の成立 方向感検査は頭蓋内に左右の耳の時間差や音圧差を作 ることで音像を正中に成立させる方法である ${ }^{17)}$ ，通常時 間差と音圧差は全く別々の検査として行う。これは感覚 レベルの検查である。これに対して Time-Intensity Trade は，時間差を作り音像を正中よりずらした状態にし，こ れに左の音圧差を作って与え，正中に戻す検查である. 気導では時間差で正中の音像を偏位させた後, 音圧差を 作って正中に戻すことも，逆に初めに音圧差を作り，音 像を偏位させてから，時間差を作って与えて正中にずら すことも可能であることを証明した ${ }^{18) 199}$. 骨導でも成立 するか研究したところ, 気導同様に成立することがわ 
T vs. I trade
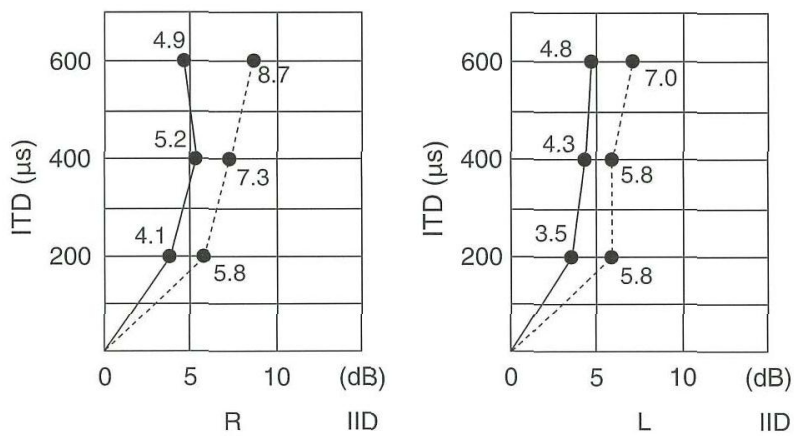

図 17 方向感検査による Time-Intensity Trade（T-IT）の評価。 実線は新開発の超磁歪型骨導素子学使用し，点線は広く 使われている電磁式骨導受話器を使用. 右耳中心の場合 と左耳中心に検査した場合も時閒差も音圧差も方向感 検查は成立（Sensation level）乙，かつ時間差をずらし音 像を正中より偏位させ音圧差で正中に戻す T-IT も成立 (Cognition level) する. 実線で示す超磁歪型骨導素子の 方が電磁型より優れていることがわかる。

かった。すなわち認知レベルで証明されたことになる20) （図 17）。しかし，実用的には音源定位（スピーカ法）で も成立することの証明が必要である。

(4)音源定位法 (スピーカ法)による両耳骨導補聴の評価 無響室で, 四 18 のように正中より $20^{\circ}$ おきの半円状に スピーカを配置し,ランダムに各スピーカより音を出し， 同定させる方法で検查を行った。両耳骨導補聴下では 図 19 に示すように,ほぼ正確に可能であることがわかっ た21).
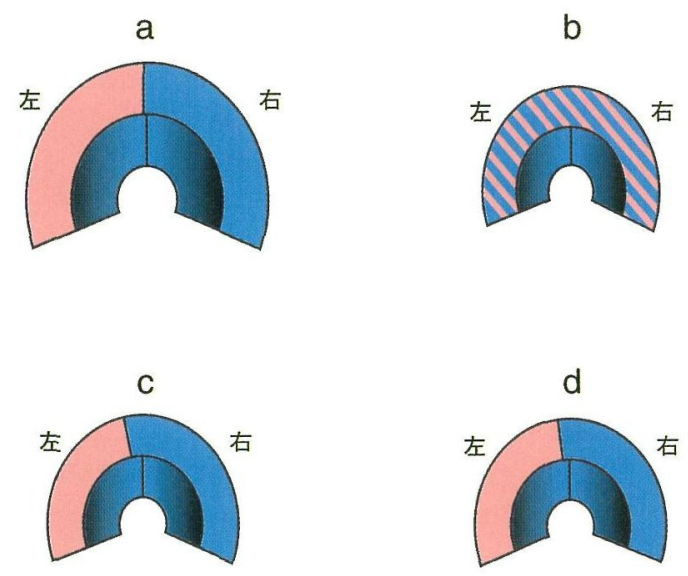

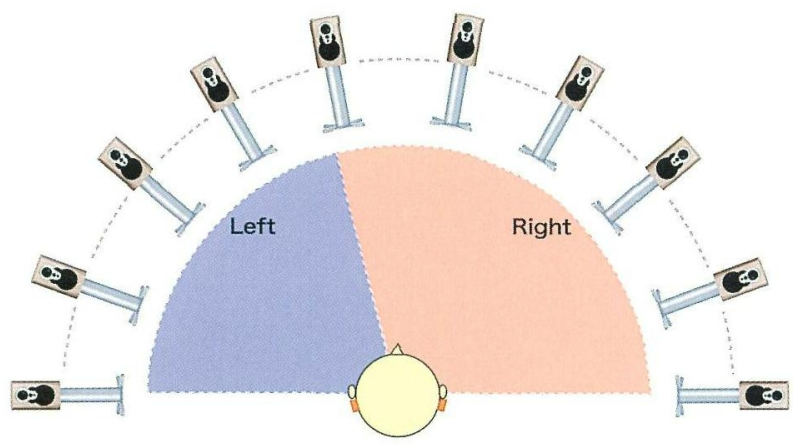

図 18 聴空間の認知検查. 音源定位法による両耳骨導の検査. 無響室にスピーカを図のごとく配置し, 認知可能な角度 について調べる.

(5)両側外耳道形成術の両耳穴式補聴下の音源定位能力 先天性両側小耳症 - 外耳道閉鎖症の両耳術後は，実用 的な聴力を得るために, 耳穴式補聴器を用いる。もとも と片耳の骨導補聴で育ったために両耳聴の能力が使われ ていなかったことになる。このような術後症例に対し， スピーカ法で音源定位検查を行うと, 正しく成立するこ とがわかった21)(図 19)。

\section{おわりに}

両側小耳症・外耳道閉鎖はわが国では毎年 $10 \sim 20$ 名 が生まれるまれな疾患である。著者がこの疾患に取り組 み始めた約 25 年前は, 耳鼻咽喉科単独で手術が行われ, 外耳道形成と聴力改善術を目的として残存耳介は上下に

図 19 音源定位法による検査結果の図解。a. 健聴者の聴空間。右は青，左は赤で示す，b．左側高度難聴。聴空間は良聴耳の右に限 定. c. 雨側小耳症・外耳道閉鎖症例の両側骨導補聴の聴空閒認知．左右のバランスがとれている．d．両側術後の耳穴式補聴 下の聴空間認知。両側骨導も気導も補聴下で正しく認知できることがわかる。e. 聴空閒の拡大を示す。青は健聴者を示し，赤 は右側骨導補聴の場合を示す。聴空間の拡大は両側骨導補聴の方が狭いことがわかる。 

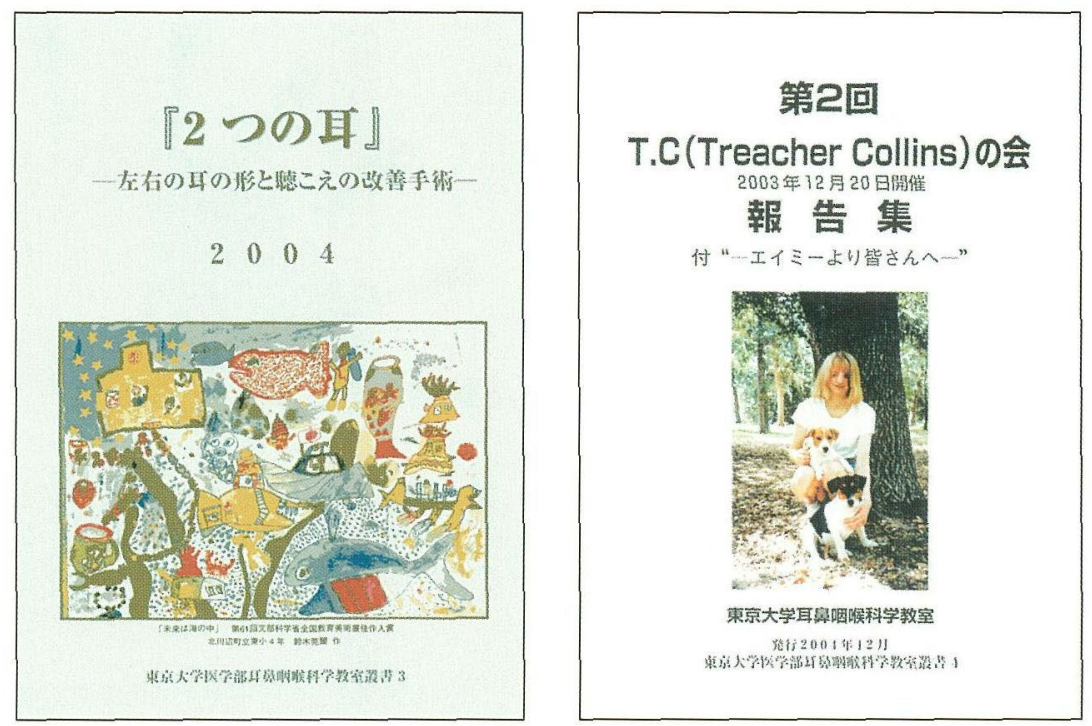

図 20 東京大学耳鼻咽喉科学教室が運営している親の会向けの冊子. 左は両側小耳症・外耳道閉鎖の両側術後の小児の作文集，右は Treacher Collins 症候群に伴う両側小耳症・外耳道閉鎖の親の会の報告書.

スプリットさせて移動する方式で，整容的には問題が あった22)。一方，耳介形成は主に形成外科で行われてき た。現在も国内外ともそうである。ただし最近の米国で は外耳道形成後は耳介にプラスチックのプロテーゼを使 らのが主流であるという。昔も今も形成外科は耳鼻咽喉 科で外耳道を作ると生涯耳漏で悩むと述べ反対すること が多い，現在は克服できている．片側の小耳症であれば 耳介形成だけでも良いが，問題は両側小耳症・外耳道閉 鎖の場合である. 1990 年のベルギーであった世界小児耳 鼻咽喉科学会で，米国テキサス大学の Jahrsdoerfer 教授 の小耳症・外耳道閉鎖の報告を聞き, 話しかけたところ, 来年講習会を行うという. 1991 年の夏, ヒューストンで の講習会に参加し，理想とする結果に近いことを知った。 著者が 1992 年東京大学附属病院に異動してから, 放射線 技師と形成外科医の有志に理想を語り，相談し，ここに 述べたような成果を上げることができるようになった。 とりわけ両側小耳症・外耳道閉鎖の患者加らも喜ばれて いることは嬉しいことである。富山県から東京大学附属 病院に通って両側耳介形成・外耳道形成を行った小学生 は自分の体験を作文に書き，県より表彰された。書きだ しの言葉は「僕は生まれた時から耳がありません」で始 まっている (図 20) 3).「東京に手術をうけに行き，この 耳ができてられしい」という内容である。しかし， Treacher Collins 症候群の子どもの場合, 乳突蜂巣も中耳
の発育も悪く, Jahrsdoerfer の側頭骨 CT 評価尺度で 5 点 以下の場合吕多く，体格も小柄で肋軟骨の発育も不十分 で両側の耳介形成と外耳道形成ができないことがある。 そのような場合も両側の骨導補聴器で良好な方向感を得 ている. 米国に Treacher Collins 症候群の女子で骨導補聴 器で育ち, 医学部を卒業し医師として活躍している人も いる ${ }^{23)}$. むう一人医学部の学生がいるという。外耳道形 成だけで鼓室形成ができなくても, 耳穴式の気導補聴器 を両耳に使用して方向感を得ることができる ${ }^{24)}$. 両耳聴 の臨床はまだまだ課題が多く, 骨導の研究13) は歴史的に は古くはないが，その最近の進歩は新しい IT 技術を フィードバックすることで始まっている．医学・工学の 革新的な技術により，両耳聴を実現したい。

\section{参考文献}

1）加我君孝：方向感検查の臨床応用. 耳鼻臨床 $92: 1263 \sim$ 1279, 1999 .

2) MacGregor FC, Abel TM, Bryt A, et al. : 顔の変形と整容の心 理 (石井英男, 台 弘訳). 59 97頁, 医䕌薬出版, 東京, 1960 .

3）加我君孝編：2 つの耳一左右の耳の形と聴こえの改善手術 一. 東京大学医学部耳鼻咽喉科学教室丵書 3, 2004.

4) 朝戸裕貴: 耳介形成術. 新臨床耳鼻咽喉科学. $53 \sim 56$ 頁, 中外医学社，東京，2003.

5) 加我君孝: 外耳道形成術 - 聴力改善術. 新臨床耳鼻咽喉科 学. $57 \sim 63$ 頁, 中外医学社, 東京, 2003 . 
6）林 裕史, 新正由紀子, 坂井有紀, 他: 先天性外耳道狭窄 閉鎖症に対する外耳道形成術後の側頭骨 HRCT. 日耳鼻会 報 109：418， 2006 .

7) Schuknecht HF : Congenital aural atresia. Laryngoscope 99 : $908 \sim 917,1989$.

8) Jahrsdoerfer RA and Lambert PR : Facial nerve injury in congenital aural atresia surgery. Am J Otol $19: 283 \sim 287,1998$.

9) Ushio M, Takeuchi N and Kaga K : Evaluation of recovery from transient facial palsy occurring after canalplasty and tympanoplasty for the treatment of congenital aural atresia. Annals ORL in press.

10）鬼塚卓弥：形成外科手術書, 南江堂, 東京, 1969.

11）新正由紀子, 坂井有紀, 加我君孝, 他：先天性小耳症 - 外 耳道閉鎖症に対する同日合同耳介および外耳道形成術一一 過性の局所感染と制御について一。 日耳鼻会報 $108: 399$, 2005.

12) Sakai Y, Karino S and Kaga K : Bone-conducted auditory brainstem-evoked responses and skull vibratory velocity measurement in rats at frequencies of $0.5-30 \mathrm{kHz}$ with a new giant magnetostrictive bone conduction transducer. Acta Otolaryngol, 2006 in press.

13）切替一郎：伝音機構と骨導に関する基礎的研究. 日本耳鼻 咽喉科学会第 58 回総会宿題報告，昭和 32 年.

14) Kaga K, Setou M and Nakamura M : Bone-conducted sound lateralization of interaural time difference and interaural intensity difference in children and a young adult with bilateral microtia and atresia of the ears. Acta Otolaryngol $121: 274 \sim$ 277, 2001.

15) Setou M, Kurauchi T, Tsuzuku T, et al. : Binaural interaction of bone-conducted auditory brainstem responses. Acta Otolaryngol 121: 486 489, 2001.
16) Sheykholeslami K, Kermany $M$ and Kaga $K$ : Bone-conducted binaural interaction. Iranian Audiology 1: $40 \sim$ 46, 2002.

17) Yamada K, Kaga K, Uno A, et al. : Sound lateralization in patients with lesions including the auditory cortex: comparison of interaural time difference (ITD) discrimination and interaural intensity difference (IID) discrimination. Hear Res 101 : $173 \sim 180,1996$.

18) Shmerber S, Sheykholeslami K, Kermany MH, et al. : Timeintensity trade of bilaterally bone-conducted sounds in normal hearing subjects. Rev Laryngol Otol Rhinol (Bord) 124:179 $185,2003$.

19) Hotta $S$ and Kaga $K$ : Comparative study of fixed time versus intensity trade and fixed intensity versus time trade tests in sound latelarization. Auris Nasus Larynx, 2006 in press.

20) Kuroki $S$ and Kaga $K$ : Better time-intensity trade revealed by bilateral giant magnetostrictive bone conduction. Neuroreport $17: 27 \sim 31,2006$.

21）黒木聡三：骨導による両耳聴の研究. 東京大学医学系研究 科博士論文， 2006 .

22) Kaga K and Suzuki J : Bilateral congenital atresia.: Auditory and vestibular testing and surgical approach. Acta otorhinolaryngol Belg $45: 51 \sim 57,1991$.

23）加我君孝編：第 2 回 T.C（Treacher Collins）の会 2003 年 12 月 20 日開催報告書 付“一エイミーより皆さんへ一”. 東京大学医学部耳鼻咽喉科学教室叢書 4, 2004.

24）岡村るみ, 中村雅一, 加我君孝: 外耳道形成術後の補聴器 装用下の音像定位. 耳鼻臨床 $90: 277 \sim 283,1997$.

別刷請求先 : 加我君孝

于113-8655 東京都文京区本郷7-3-1

東京大学医学部附属病院耳鼻咽喉科学教室 